\title{
Organic Catfish Feed From Cow Manure
}

\author{
Dimas Muhammad Rosyid ${ }^{1)}$, Sri Widyastuti ${ }^{2)}$ \\ Environmental Engineering Study Program, Faculty of Civil Engineering and Planning \\ Universitas PGRI Adi Buana Surabaya \\ E-maiil : Sriwidyastuti@unipasby.ac.id
}

\begin{abstract}
Artificial feeding feeding is given as additional feed to accelerate the process of fish enlargement. Self-processing of feed can be conducted by utilizing cow manure through the fermentation process and the addition of an effective microorganism (EM4) solution. This research used 3 treatments which are fermentation for 5, 9, 11 days with each dry cow manure of $2 \mathrm{~kg}$ with water content of $19 \%$. The resulting feed was then tested for quality to determine protein and fat content. The 3 treatments produced levels of nutrient protein and fat as follows: protein levels in treatment I (6.16\%), II (7.57\%), III (7.68\%) while the fat content in treatment I $(0.15 \%)$, II $(0.50 \%)$, III $(0.60 \%)$. The results of feed from all treatments were given to catfish. Catfish growth was observed for 10 days. Weight gain from the initial weight of $400 \mathrm{gr}$, on treatment 1 to the 10th day: 500 grams, the second treatment to the 10th day weighing 600 grams, treatment 3 to the 10th day: 1000 grams. Resulted feed haven't met Quality Standards for SNI Feed No SNI: 01-4087-2006.

Keywords: Cow manure, Fermentation, EM 4, Quality test of Artificial feeding, Protein and Fat.
\end{abstract}

\section{INTRODUCTION}

Feeding is an important component as fish energy in doing activities and grow. In nature, fish can meet their food needs with feed available in nature. Feed from nature is always in accordance with the conditions of the fish. However, in a fish farming environment, fish can't choose feed and they depend on artificial feed. The percentage of operational costs of feed in aquaculture activities is $50-70 \%$ of the total cost. The feed is made of natural food, but in intensive fish enlargement, its maintenance is carried out using artificial feed. Thus, good management must be conducted so that the feed given is really effective in fulfilling nutrition in fish. Nutritional regulation of fish must be able to meet the needs of protein by 20 - $60 \%$, carbohydrates by $30 \%$, fat by $4-8 \%$, and vitamins and minerals in accordance with fish needs. This composition is used in making feed using basal protein and supplements.

Catfish (clarias bathracus) is type of freshwater fish with high nutrition. Catfish meat contains omega- 6 fatty acids which are beneficial for heart health. Besides, catfish also contains high enough protein of $15.6 \mathrm{mg}$ (Anonimus, 2013). Catfish are type of fish which can be considered to be very easy in feeding, in addition to eating factory-made pellets, natural food and additional feed for the process of raising catfish in search of people. Natural food or live food is especially needed when catfish are still small or in the early stages of hatchery.

One of the efforts to enlarge catfish is with fertilization which is useful for the supply of growth media for natural food for catfish, especially in seed stages (Kholish Mahyudin, 2008). Pellets can be carried out better if we provide natural food that is always in the pond by providing organic and chemical fertilizers in the enlargement pond. Fertilizing to encourage the growth of phytoplankton, the presence of phytoplankton can encourage the growth of zooplankton populations in order to increase the availability of natural feed (Kholish Mahyudin, 2008). The existence of zooplankton which is a natural food that contains animal protein is expected that catfish will grow faster and reach the expected weight. Nur Solikin's research (2016) shows that the highest addition of catfish weight in pond treatment is only given the addition of organic fertilizer and the microscopic observation of ponds with organic fertilizer treatment has more types of plankton. 
The additional feed for catfish is often given when enlargement or maintenance of catfish broodstock (Remi, 2013). Several types of raw materials can be used to make Organic Catfish feed (Anonymous, 2013). The higher the nutrient content of nitrogen will make the raw material decompose faster. This is because decomposing microorganisms need nitrogen nutrients for their development. The nutrient element of nitrogen is used by microorganisms for protein synthesis and formation of protoplasms. (Anonymous, 2013).

Physically, Animal manures which can be used for fertilizer after undergoing composting is not similar (color, appearance, texture, and moisture content) to the condition of the original material. Whereas, chemically it contains $60-70 \%$ organic matter, $2 \%$ substance $\mathrm{N}, 1 \%$ substance $\mathrm{P} 2 \mathrm{O} 5$, and $1 \%$ substance $\mathrm{K} 2 \mathrm{O}$. Types of animal mature that can be used are manure from cow, buffalo, rabbit, chicken and goat.

Cow manure can be used as artificial feed for catfish by processing a kind of organic fertilizer that will stimulate the growth of natural feed as well as the media for the development of complex microorganisms in catfish ponds (Anonymous, 2013).

The research conducted by Zulhelmi, Cut Aida Fitri, and M. Aman Yaman (2016), they made organic pellet feed made from cow manure waste, soybean meal, fine bran and probiotics. The results showed the treatment of cow's manure waste waste food had a very significant effect $(\mathrm{P}<0.01)$, on body weight, weight gain, and consumption of catfish catfish rations, but it was not significant effect $(\mathrm{P}>$ 0.05 ) on feed conversion and efficiency. From the results of this result, it can be concluded that organic pellet feed from cow manure can stimulate the growth of African catfish. Feed was applied to 800 catfish with an average weight of 1.55 grams / head and a length of $10-11 \mathrm{~cm}$.

So far, utilization of cow manure, both feces and urine, is still limited to the use of fertilizers and biogas (Sunanjaya et al., 2011). Thus, it is necessary to research the processing of livestock waste as feed material in order to make the economic value will be higher

Cow manure is waste from cattle business which is dense and in the process of disposal is often mixed with urine and gas, such as methane and ammonia. Nutrient content in cow manure varies depending on the state of the level of production, type, amount of feed consumption, as well as individual livestock themselves (Abdulgani, 1998). Cow manure is used as a result of digestion of cattle and animals from the Bovinae subfamily. Cow manure varies in color from green to black, depending on the food it eats. After exposure to air, the color of cow manure tends to darken.

In the previous research conducted by Agus Priyanto (2011), he utilized the use of biogas waste (sludge) as a substitute for pellet feed, from the results of research at the Quality Hall of Fish Feed Testing (BPMT) producing Protein (Rough 7.83\%), Fat (crude 3.28\%).

Guntoro et al. (2013) stated that cow manure fermented with inoculants containing microbes from the digestive tract of termites for 5 days which can increase protein content from $7-8 \%$ to $14.80 \%$ and significantly reduce crude fiber content.

\section{Research Method}

The tools used in this research were 3 barrels with a capacity of 30 liters. The material used dried cow manure from Jetis Wonokromo Surabaya weighs $2 \mathrm{~kg}, 19 \%$ water content and EM4 solution. The research step was carried out through the process of hydrolysis of cow manure for 24 hours using an EM4 solution of 200 milliliters, followed by a fermentation process for 5, 9, 11 days. After the fermentation process of organic catfish feed, it was tested for fat and protein content at the Baristand Laboratory in Surabaya.

\section{Result and Discussion}

The use of raw material for dumbo catfish feed from expired processed human food ingredients caused debate for consumers of farmer-made feed products. The problem is that the product produced has not been tested in a laboratory manner so that the achievement of standard quality requirements is still questionable.

In addition, consumers want to know whether the product is safe for fish. Food safety for fish also has direct implications for humans who consume it. Furthermore, the question arises regarding the stability of fish 
growth, especially when compared to the feeds of the large companies that have been present and already have the attributes of technoware and humanware in accordance with standard provisions.

The most effective way to find out the question above is by researching whether the technology used by farmer groups has met the relevant Indonesian National Standard (SNI) quality requirements. In the context of Dumbo catfish feed, SNI documents which are used as research references are SNI 01-4087-2006.

Nutrient protein content of the study results in treatment I: $6.16 \%$, II: $7.57 \%$, III: $7.68 \%$ while the fat content in treatment I: $0.15 \%$, II: $0.50 \%$, III: $0,60 \%$. The following results are the percentage of protein and fat in each treatment
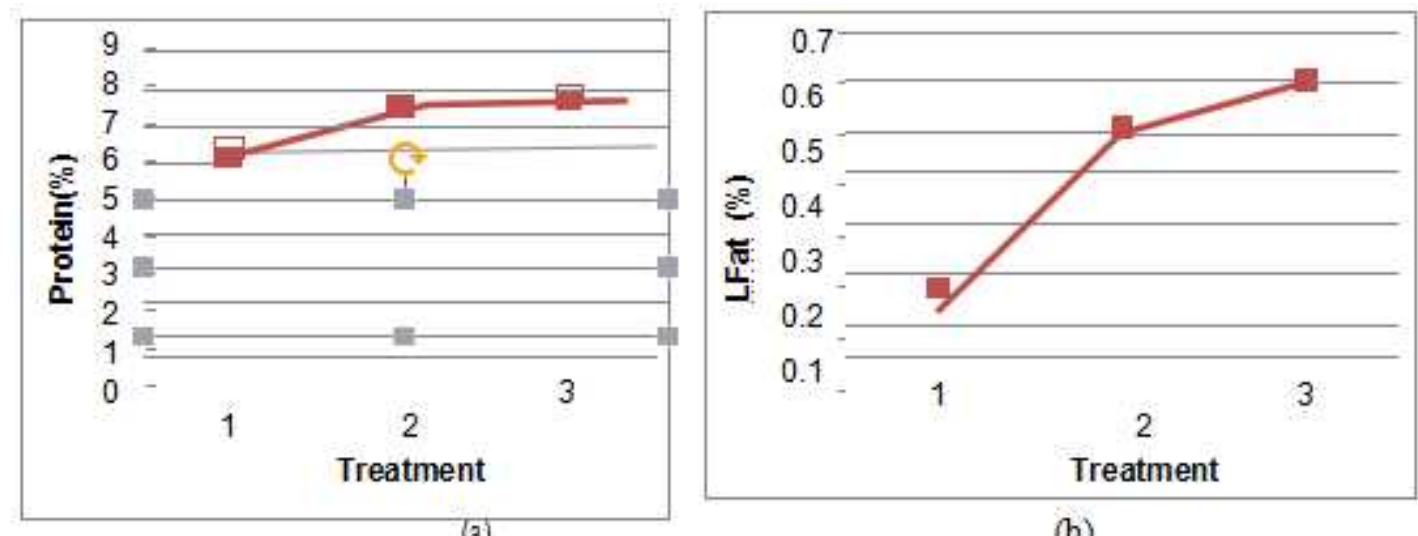

(b)

Figure 1. Analysis Result of Test Feed Treatment

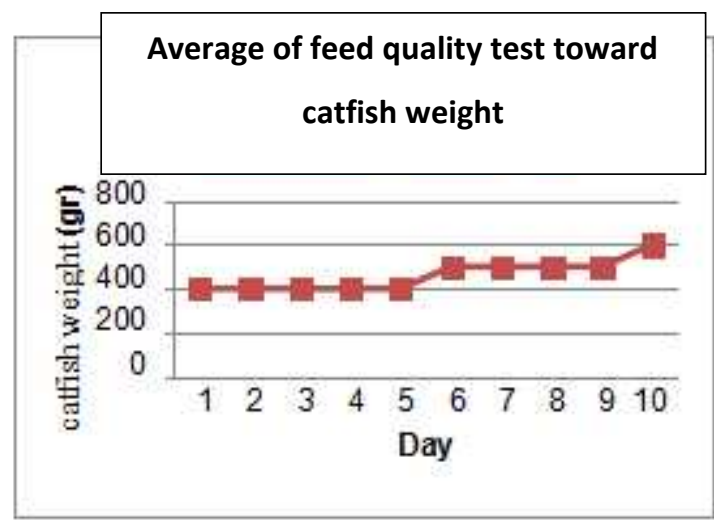

(a)

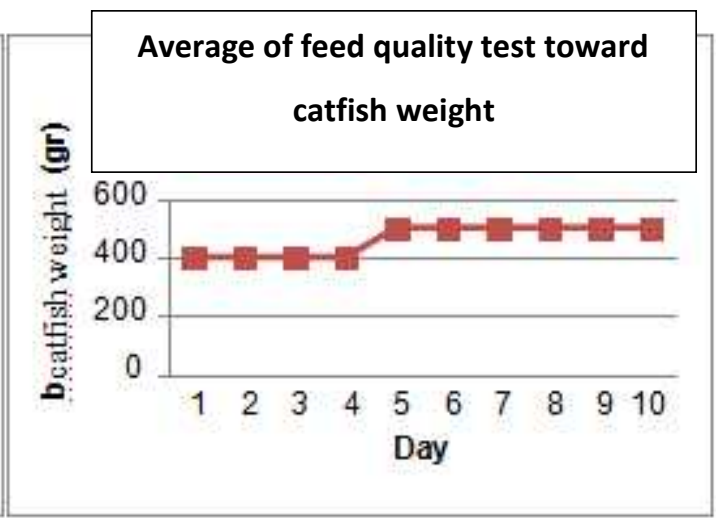

(b)
Figure 2. average of cat fish weight of treatment 1
Figure 3. average of cat fish weight of treatment 2 


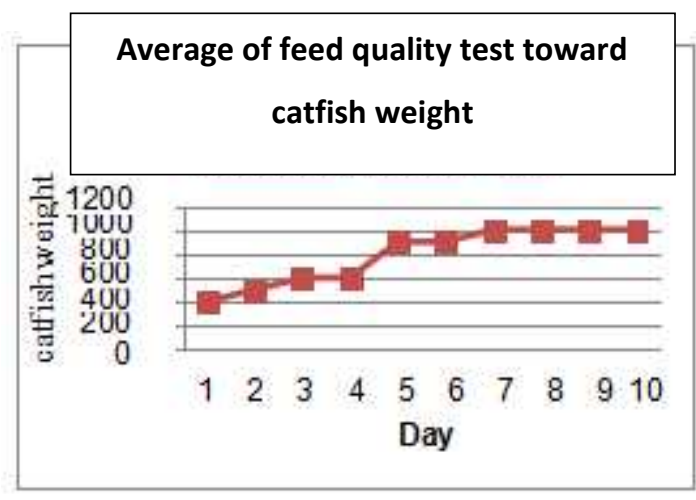

(c)

Figure 4. average of catfish weight of treatment 3

From the figure (a) treatment 1 , it was conducted feed quality test for 10 days, with an initial weight of 400 grams of fish, a final weight of 500 grams. Figure (b) the second treatment with an initial weight of 400 grams of fish obtained a final weight of 600 grams, and with picture (c) of the third treatment with an initial weight of 400 grams of fish obtained a final weight of 1000 grams.

Based on the quality requirements of artificial fish feed, the resulting feed does not meet the quality standards of artificial feed.

Table 2. Quality Standard of Dumbo Catfish Feed

\begin{tabular}{llll}
\hline No. & Test Type & Unit & Requirement \\
\hline 1. & Water content & $\%$ & $<12$ \\
2. & Ash Content & $\%$ & $<13$ \\
3. & Protein Content & $\%$ & $>30$ \\
4. & Fat Content & $\%$ & $>5$ \\
5. & Crude fiber content & $\%$ & $<6$ \\
6. & Non protein nitrogen & $\%$ & $<0,2$ \\
7. & Diameter of pellet $\mathrm{mm}$ & $\mathrm{mm}$ & $<2$ \\
8. & Floating rate & $\%$ & $>80$ \\
9. & Stability in water & mengapung/tenggelam & Menit $>15 / 5$ \\
\hline
\end{tabular}

Source: (SNI : 01-4087-2006)

The addition of EM4 cow manure to produce organic catfish feed highly affects the process of breaking down nutrient components in cow manure into protein and fat. Of the three treatments, the processed feed results were made application and observations on catfish for ten days. Catfish Growth Rate from observations that have been made obtained data on biomass weights of catfish for ten days and the results of analysis of variance of processed research data. Although it does not meet the quality standards of artificial feed, the results of the study indicates that the need for protein and fat and is sufficient and in accordance with the needs of fish for growth, According to Lestari (2000).
Bio starter solution is a solution used in the process of fermentation of catfish food. Thus, the resulting catfish feed can last a long time and increase the appetite of catfish. Bio starter is only used as another animal feed starter for fermentation methods that are very profitable and have high economic value ( GARG, MR1998).

For fish farming business, besides location/place and condition of water, feed is one of the main supporting factors of fish growth and health. Good fish feed and supported by proper feeding procedures, both in terms of time and use so that fish farmers can get the maximum benefit from the results of cultivation (Nurhasan, 2015) 
Research by Zulhelmi, Cut Aida Fitri, M. Aman Yaman (2016) showed the effect of feeding from cow manure waste without death or survival rate, but instead, showed that feed from manure can maintain fish survival. According to Yuniarti (2006), several factors that affect the survival rate include disease and water quality of catfish, attacking diseases are usually related to water quality, good water quality will reduce the risk of fish getting sick and increase survival rates (Survival rate). According to Murjani (2011), fish survival highly depends on the adaptability of fish to food and the environment, fish health status, stocking density, and sufficient water quality to support growth. Water quality directly or indirectly water quality.

The use of fermented cow manure to $20 \%$ in free-range chicken ration has no effect on egg productivity, and FCR (Feed Convertion Ratio). The combination of the use of probiotics in rations containing cow manure causes a significant decrease in FCR. The use of cow manure in rations up to the level of $20 \%$, both without or in combination with probiotics, has no effect on the health or

\section{References}

1. Agus Priyanto, 2011. Pemanfaatan Limbah Biogas (sludge) Sebagai pengganti Pakan Pellet Komerial Untuk Meningkatkan Perkembangan Kematangan Gonad Dan Pertumbuhan Benih Lele ( Clarias gariepnus ). Universitas Brawijaya.

2. Anonimus, 2003. Bulu Unggas Untuk Pakan Ruminansia. Warta Penelitian dan Pengembangan Pertanian. Volume 25 No. 6.

3. Abdulgani, I. 1988. Seluk Beluk Kooran Sapi serta Manfaat Praktisnya.Fakultas Peternakan, Insitut Pertanian: Bogor.

4. Anonim, 2011. Pakan Bergizi untuk Lele dari Limbah Ternak (Biogas). http ://www.pakkatnews.com

5. Anonim. 2013. Cara membuat pakan lele organik.

http://www.indoaqua.net/2013/01/cara-me mbuat-pakan-ikan-lele-organik.html

6. Azis Andre Dwi Alamsyah', Joddy Christyawan, Agnes Priska Tiarasukma, Vita Paramita., 20013. Pembuatan mortality rate of chickens. The use of processed cow manure up to the level of $20 \%$ in the ration either without or in combination with probiotics has no effect on the physical composition of eggs (Guntoro, 2016).

The higher use of cow manure causes the FCR tends to increase. This is due to the increasing level of use of cow dung in the ration causing an increase in crude fiber content and the higher crude fiber causing an increase in FCR (Nompo and Pantjawidjaja, 2013).

\section{Conclusion}

Based on the result of the research, it can be concluded as follow:

The manufacture of organic catfish feed made of a mixture of dried cow manure, 200 $\mathrm{ml}$ and EM4 solution from the 3 treatments with different variations in nutrient content, from the highest is the $3^{\text {rd }}$ treatment with Protein content: $7.68 \%$ Fat: $0.60 \%$. The $3^{\text {rd }}$ treatment that has the highest nutrient content does not meet the quality standards of feed production.

Pangan Ternak Lele Organik Berbahan Baku Protein Dari Bulu Ayam Dengan Metode Fermentasi BIO. Jurnal Teknik Kimia Unversitas Diponegoro Semarang.

7. GARG, M.R 1998. Role of bypass protein in feeding ruminants on crop residue based diet.Review. Asian Aust. J. Anim.Sci.11(2) : 107-116

8. Guntoro, S., M. R. Yasa, A.A.N.B.S. Dinata, I.W. Sudarma. 2013. Pemanfaatan Feses Sapi Untuk Pakan Itik Bali Jantan. JPPTP 16 (2): 77-84.

9. Indah Susantun dan Muhamad Saifullah, 2014, Penyuluhan Pemanfataan Kotoran Hewan Sebagai Pakan Lele , Seri Pengabdian Masyarakat 2014 Jurnal Inovasi dan Kewirausahaan, Vol. 3, No. 3, September 2014

10. Yuniarti. 2006. Pengaruh Kepadatan Benih Ikan Lele Dumbo (Clarias sp) Terhadap Produksi pada Sistem Budi daya dengan Pnegndalian Nitrogen melalui Penambahan Tepung Terigu. Skripsi. Bogor. 
11. Lestari.2000, Ulasan: exsplorasi enzim termostabil dari mikroba termofil, Hayati. $7: 0854-8587$

12. Madinawati, Serdiati, N, dan Yoel. 2011. Pemberian Pakan Yang Berbeda Terhadap Pertumbuhan Dan Kelangsungan Hidup Benih Ikan Lele Dumbo (Clarias gariepinus). Media Litbang Sulteng. IV (2) : 83 - 87, (Diakses Agustus 2014)

13. Murjani, A. 2011. Budidaya beberapa varietas ikan sepat rawa (Trichogaster trichopterus Pall) dengan pemberian pakan komersial. Jurnal Fish Scientiae.1(2): 214-233.

14. Nompo, S dan Pantjawidjaja. 2010. Pengaruh Energi Protein Ratio Ransum Lokal yang Berbeda Terhadap Performan dan Berat Karkas Broiler. [Online], Available : "http:// repository.unhas.ac.id". [2 agustus 2015]

15. Nur Solikin, 2016, Penambahan Unsur Hara Makro Dan Mikro Pada Media Pembesaran (Kolam) Terhadap Penambahan Berat Lele Dumbo (Clarias Gariepinus). Universitas Nusantara Kediri

16. Remi. 2013.Pakan tambahan lele berasal tumbuh-tumbuhan. https://ternakpedia.com/736/pakan-tamba han-lele-berasal-tumbuh-tumbuhan/

17. Suprio Guntoro, Anak Agung Ngurah Badung Sarmuda Dinata, I Wayan Sudarma,2016, Kombinasi Penggunaan Tepung Feses Sapi Dalam Ransum dan Pemberian Probiotik Pada Ayam Buras Petelur , Jurnal Biologi Volume 20 No.2 DESEMBER 2016 Halaman 47 - 52 ISSN : 1410-5292

18. Sunanjaya, I.W., A.A.N.B. Kamandalu dan M. Astika. 2011. Kajian Pengolahan Limbah Menjadi Pupuk Organik Bermutu Dengan Beberapa Dekomposer di Desa Katung, Kec. Kintamani - Kabupaten Bangli. Buletin Teknologi dan Informasi Pertanian. Balai Pengkajian Teknologi Pertanian (BPTP) Bali. 9 : 13-19.

19. Zulhelmi , Cut Aida Fitri M. Aman Yaman, 2016, Pemanfaatan Limbah Feses Sapi sebagai Pembuatan Pakan Pelet terhadap Pertambahan Berat Badan Ikan Lele Dumbo, Jurnal Ilmiah Mahasiswa Pertanian Unsyiah Volume 1, Nomor 1, November 2016 www.jim.unsyiah.ac.id/JFP 